\title{
Current status and prospects of plant biotechnology in Kazakhstan
}

\author{
Kabyl Zhambakin ${ }^{1} \cdot$ Kuanysh Zhapar $^{1}$
}

Received: 12 December 2019 / Accepted: 29 January 2020 / Published online: 11 February 2020

(c) The Author(s) 2020

\begin{abstract}
Biotechnological methods are becoming an integral part of biological research. This review presents some of the most significant scientific results of Kazakhstan biologists in the field of plant biotechnology over the past 10 years. One of the recent important areas of application of biotechnological methods is the conservation and study of plant genetic resources and bioremediation. Studies on the flora lead to the identification of new sources of previously unknown biologically active materials, especially among wild plants growing in Kazakhstan. In addition, various biotechnological approaches are used to increase the efficiency of breeding practices for the production of new crop varieties.
\end{abstract}

Keywords Kazakhstan $\cdot$ Biotechnology $\cdot$ Plant breeding $\cdot$ Molecular markers $\cdot$ Phytoremediation $\cdot$ Genetic resources

\section{Introduction}

The current status of plant biotechnology in Kazakhstan is characterised by a certain improvement, which is undoubtedly a result of the development of biotechnological approaches for preserving and exploring genetic resources, bioremediation, crop breeding as well as medicinal applications. However, it should be noted that the main reason why Kazakhstan remains far behind the developed countries is insufficient funding of science. Particularly, over the past 3 years, the total cost of research and maintenance of the infrastructure of scientific organisations did not exceed $0.17 \%$ of the country's GDP (Belyaeva et al. 2019) (Fig. 1), which is significantly lower than that of the neighbouring countries such as Russia (1.1\%) and Uzbekistan (0.19\%) (World Bank Data 2017). Lack of funding most negatively affects fundamental sciences, such as plant biology. Nevertheless, Kazakhstan has achieved some progress in the development and use of modern biotechnological methods, such as plant cell and tissues culturing, molecular marking and genetic engineering. A number of scientific institutions and universities are involved in plant biotechnology research, and most of the significant and promising results in this area have been obtained by the Institute of Plant

Kuanysh Zhapar

zhapar.zk@gmail.com

1 Institute of Plant Biology and Biotechnology, Timiryazev str. 45, 050040 Almaty, Kazakhstan
Biology and Biotechnology (IPBB, Almaty), the National Center for Biotechnology (NCB, Nur-Sultan), Aitkhozhin Institute of Molecular Biology and Biochemistry (IMBB, Almaty), Al-Farabi Kazakh National University, (KazNU, Almaty) and L.N. Gumilyov Eurasian National University (ENU, Nur-Sultan).

\section{Fundamental research}

Fundamental biological science in Kazakhstan was developed in the middle of the last century and is mainly associated with the large-scale development of virgin lands. Most cutting-edge studies are performed in the area related to the development of crop resistance to environmental stress factors due to the sharp continental climate of Kazakhstan. With the collapse of the Soviet Union and the subsequent destruction of the infrastructure of scientific institutions, as well as the system of training scientists, fundamental research in the country was significantly restricted. However, over the past 10 years, the interest in fundamental science has been growing due to joint projects with leading global research institutions.

Some research institutions with projects that showed the most promising results in plant biotechnology are presented below.

Advanced research in cell biology and molecular genetics is being conducted at L.N. Gumilyov Eurasian National University, including the effect of viral infection on the 


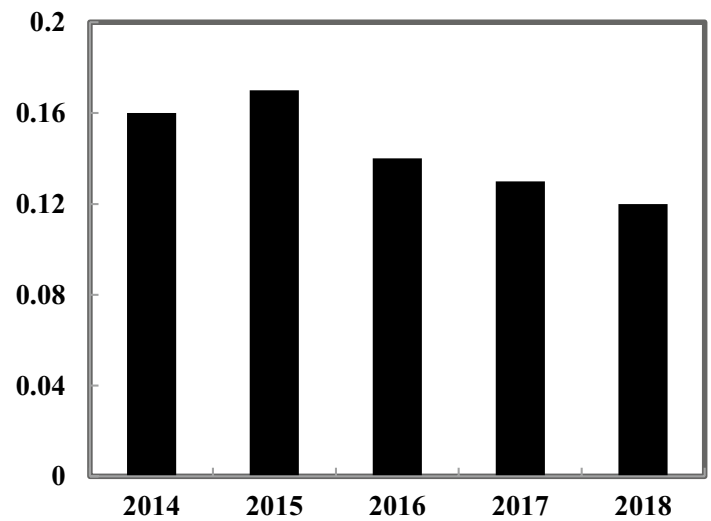

Fig. 1 Proportion of internal costs for R\&D in the GDP of Kazakhstan, \% (Belyaeva et al. 2019)

activation of oxidative stress enzymes in plants. For the first time, the role of the enzyme aldehyde oxidase in the activation of plant defence mechanisms as a response to viral pathogen invasion is shown. Moreover, the study demonstrated the participation of the viral suppressor of RNA interference in the increase of reactive oxygen species levels in plants. An important role of molybdenum ions in the development and elongation of barley root system was also discovered; this metal had a stimulating effect on salt resistance (Batyrshina et al. 2018).

Al-Farabi Kazakh National University has traditionally been holding the leadership in biochemistry. For instance, a study conducted in 2014 determined that the putative wheat AP endonuclease, referred to as TaApe1L, contains AP endonuclease, 3'-repair phosphodiesterase, 3'-phosphatase and $3^{\prime} \rightarrow 5^{\prime}$ exonuclease activities. Surprisingly, in contrast to bacterial and human AP endonucleases, adding $\mathrm{Mg}^{2+}$ and $\mathrm{Ca}^{2+}(5-10 \mathrm{mM})$ to the reaction mixture inhibited TaApe1L activity, whereas the presence of $\mathrm{Mn}^{2+}, \mathrm{Co}^{2+}$ and $\mathrm{Fe}^{2+}$ cations $(0.1-1 \mathrm{mM})$ strongly stimulated the DNA reparation activity. After the optimisation of the reaction conditions, it was found that wheat enzyme requires a low divalent cation concentration $(0.1 \mathrm{mM})$, a slightly acidic $\mathrm{pH}$ (6-7), a low ionic strength $(20 \mathrm{mM} \mathrm{KCl})$ and a temperature at around $20{ }^{\circ} \mathrm{C}$. Steady-state kinetic parameters of enzymatic reactions indicate that TaApe1L removes 3 '-blocking sugar-phosphate and 3'-phosphate groups with high efficiency ( $\mathrm{kcat} / \mathrm{KM}=630$ and $485 \mu \mathrm{M}$ min, respectively), but possesses an extremely low AP endonuclease activity in comparison to human homologue APE1 (Joldybayeva et al. 2014).

The IMBB was the first to establish a new cap-independent mechanism of mRNA binding to the 40S ribosomal subunit during translation initiation in plants. This mechanism is explained by a complementary interaction between the $5^{\prime}$-untranslated sequence (5'-NTP) of mRNA and the central domain of $18 \mathrm{~S}$ rRNA. It was experimentally proven that the increasing level of 5'-NTP complementarity to this $18 \mathrm{~S}$ rRNA region leads to a multiple increase in the efficiency of mRNA translation. The results are highly important not only in fundamental, but also in applied science, allowing to construct artificial mRNAs with high translational activity. These highly active mRNAs are necessary in cellfree protein synthesis technology and in genetic engineering to obtain transgenic plants producing valuable proteins (Akbergenov et al. 2003, 2004).

The IPBB has developed a highly sensitive and highly specific identification system for Erwinia amylovora, a causative agent of bacterial burn in fruits, which is based on the loop isothermal amplification (LAMP) method, which does not require agarose gel electrophoresis. It only needs an amplifier with the ability to conduct analyses in the field, and this system is 100-1000 times more sensitive than PCR (Galiakparov et al. 2019).

\section{Conservation and study of genetic resources of the Kazakhstan flora}

Traditionally, biological diversity in Kazakhstan has been the basis of biological research in the country. Kazakhstan has rich and diverse natural resources, and studying these resources is not only important from a fundamental point of view, but also carries a huge potential in applied science. In this regard, for the first time in Kazakhstan, the IPBB has developed a modern technique for the cryopreservation of plant tissues and organs in liquid nitrogen $\left(-196{ }^{\circ} \mathrm{C}\right)$, which is used for reliable and long-term preservation of valuable genetic materials in a viable state. A cryogenic collection of economically important crops (varieties, hybrids and wild forms of apple, currant, raspberry, cherry, strawberry, grape, potato, rice, etc.) has been established and is constantly being updated. A list of cultures in the collection was included in the Botanic Gardens Conservation International (BGCI) database (Romadanova et al. 2016a). Cryopreservation is not only used for the long-term preservation of the plant genetic diversity in Kazakhstan, but also for the recovery of crops from phytopathogens (Kushnarenko et al. 2017; Romadanova et al. 2016b).

Modern genomic technologies and bioinformatics are widely used to study the genetic diversity of endemic, rare, endangered and wild-growing valuable plant species of Kazakhstan. In a study conducted in IPBB, three DNA markers, namely ITS, matK and rbcL were selected to analyse the genetic diversity of the collected plants. The ITS is a hallmark of the nuclear genome, whereas matK and rbcL are markers of the chloroplast genome. Results of the study were used for the statistical analysis of population diversity, using the MEGA 6 software. Genetic diversity was studied 
at intraspecific, intrageneric and intrafamily levels of plant organisation. Based on the phylogenetic analysis of the studied plant molecular systematics, hypotheses on speciation processes were put forward on examples of studies of individual species, genera and families (Abugalieva et al. 2017; Almerekova et al. 2017; Turuspekov et al. 2017a, b).

\section{Kazakhstan flora in pharmacology}

Kazakhstan contains a great variety of medicinal plants that produce phytochemicals with high biological activity. In particular, species such as licorice and kok-saghyz are among the most popular ones.

Licorice (Glycyrrhiza glabra L.) is widely used in Kazakhstan as a medicinal plant both for therapeutic and preventive purposes. The interest in studying this plant is growing due to its in vitro antitumor activity on human myeloid leukaemia.

Nowadays, myeloid leukaemia is a serious issue in Kazakhstan, calling for the development of novel therapeutic approaches based on the use of plant phytochemicals with anti-leukaemic activity. For instance, a joint study done by IPBB and the Ben Gurion University of Negev (Beersheba, Israel) in 2014 showed that licorice root extract inhibited the growth of leukaemia cells (Bari et al. 2014).

Another promising plant species is kok-saghyz (Taraxacum kok-saghyz), also known as Kazakh dandelion or Russian dandelion, which is listed in the Red Book of Kazakhstan and thereby protected by the Government. Roots of this plant accumulate high amounts of natural rubber (up to 27\%) and inulin (up to 40\%). Natural rubber of kok-saghyz does not cause allergies and is used in the manufacturing of a number of medical products, such as gloves for surgeons. Inulin is a polysaccharide with prebiotic properties and used as a part of preventive and therapeutic measures for patients with type II diabetes as well as for people in risk groups, such as those with hereditary factors (Uteulin and Baitulin 2017). The IPBB is the author of the first Kazakhstan variety of Dandelion kok-sagyz "Saryzhaz". Saryzhaz roots contain up to $40 \%$ of inulin polysaccharide and up to $10 \%$ of nonallergenic natural rubber for the manufacturing of a wide range of medical products (Uteulin et al. 2018).

Nowadays, Kazakhstan researchers are discovering new sources of valuable phytochemicals to apply in pharmacology. The international research and production holding "Phytochemistry", located in Karagandy City, is one of the world-leading organisations developing plant-derived medicines. On the basis of the laboratory, a full technological cycle has been developed from the production of medicinal raw materials, including its processing, to the release of finished dosage forms of phytopreparations. They have studied over 500 species of plants growing in Kazakhstan, of which more than 400 showed promising results in terms of obtaining new biologically active compounds. Up to today, 72 new original herbal remedies have been developed and introduced into production. More than 2000 new derivatives have been synthesised, a number of which showed significant antimicrobial, antiviral, antifungal, antitumor, analgesic, phagocyte-stimulating, anthelmintic, neurotropic and other types of activities (Adekenov 2016, 2017; Schepetkin et al. 2018; Suleimenov et al. 2010).

The IPBB identified valuable sources of essential oils in the wild flora of Kazakhstan. For the first time, the components of the essential oils of Kotukhov wormwood (Artemisia kotuchovii Kupr.), Ili honeysuckle (Lonicera iliensis Pojark.) and Iliy ferula (Ferula iliensis Krasn. Ex Korovin) (Schepetkin et al. 2015; Utegenova et al. 2018) were identified.

Antimicrobial activity against Staphylococcus aureus, Escherichia coli and Candida albicans was determined in seven samples of essential oils, including an endemic species Ferula iliensis (ferula of Ili), in which it was observed for the first time. The antioxidant activity of essential oils was tested in five species from Kazakhstan. For the first time, it was established that the essential oil isolated from ferula of Akichken (Ferula akitschkensis) and ferula of Ili (F. iliensis), as well as their six components (sabinene, $\beta$-pinene, $\gamma$-terpinene, depleted acetate, geranyl acetone and 2-nonenal), activated $\mathrm{Ca}^{2+}$ influx into neutrophils. The essential oil obtained from Kotukhov wormwood stems inhibited fMLF tripeptide-induced $\mathrm{Ca}^{2+}$ entry into human neutrophils, with a minimum inhibitory concentration of $12.5 \mu \mathrm{g} / \mathrm{ml}$. This is the first mentioning in the scientific literature of the effect of essential oils and their components on the level of $\mathrm{Ca}^{2+}$ in human neutrophils (Kushnarenko et al. 2016; Schepetkin et al. 2016).

\section{Phytoremediation}

Nowadays, worldwide threats to ecosystems and biodiversity are multi-dimensional, from localised habitat loss because of pollution to the global effects of climate change. Soil contamination by xenobiotics around industrial areas in agriculture, oil and gas complexes, mining and processing industries as well as military test sites considerably threatens environmental and human health. One of the essential steps to prevent toxic effects of pollutants on the environment and human health is the remediation of contaminated soils, either via the separation of xenobiotics from the soil or via physicochemical soil treatment. These technologies are extremely energy-intensive and require large investments. As worldwide practice shows, phytoremediation is the most cost-effective and environmentally friendly method 
of restoring contaminated soils, representing a good alternative to physical or chemical methods of reclamation.

According to the "International Scientific and Technical Programs and Projects for 2013-2015", the project "Developing Phytoremediation Methods for Soils Contaminated with Pesticides based on the Construction of Microbial and Plant Associations" was completed at the IPBB. As a result of the project, the efficiency of phytoremediation of soils contaminated with organochlorine pesticides using plantmicrobial symbiotic systems has increased. The advantage of using the recommended wild plants for phytoremediation lies in the absence of expensive purification procedures. Optimising environmental conditions using a natural destructor allows to increase the restoration of land contaminated with persistent organic pesticides (Nurzhanova et al. 2013).

In 2016, the IPBB won a NATO G4867 grant for the project "New Phytotechnology for the Restoration of Contaminated Lands", the priority "Environmental Protection and the Transition to a Green Economy"; years of implementation 2016-2019. Performers: University of Kansas, USA; National University of Life and Environment, Ukraine; Jan Evangelista Purkyne University, Czech Republic; Lviv Polytechnic National University, Ukraine (Nurzhanova et al. 2019).

\section{Molecular markers in plant breeding}

There are several positive examples for the use of molecular markers in crop breeding. At the same time, several factors can limit the implementation of these technologies in practical breeding. Work in this direction should be carried out in close contact with molecular geneticists and breeders. The IPBB formed a deep history of cooperating with the main breeding institutes of the republic for strategic crops for the country.

Wheat production in Kazakhstan is seriously constrained by several biotic stresses, including rust diseases (stem, stripe and leaf rusts) and leaf spotting diseases (tan spot, Septoria tritici blotch).

Of the 170 wheat entries screened for predominant stem rust, Puccinia graminis f. sp. tritici races from Kazkahstan and Kenya, 21 entries resistant to Kazakhstani Pgt races and 10 entries resistant to race $\mathrm{Ug} 99$ were identified. The genes Sr24/Lr24 were identified in seven wheat entries (Kokhmetova et al. 2011).

The evaluation of Central Asian wheat germplasm for stripe rust Puccinia striiformis f. sp. tritici (Pst) resistance allowed to select the lines KR12-18 (\#18) and KR11-03 (\#5) as new varieties in Uzbekistan and Georgia, respectively. Analyses of 152 Kazakhstani Pst samples showed avirulence of $\operatorname{Yr} 5, \mathrm{Yr} 10$ and $\mathrm{Yr} 15$ genes. The genes $\mathrm{Yrl}$ in
KR12-5075 and Yr6 in KR11-03 and KR12-5003 were postulated (Kokhmetova et al. 2018a, b).

To effectively use leaf rust Puccinia recondita $\mathrm{f}$. $\mathrm{sp}$. tritici resistance genes, $(\mathrm{Lr})$ winter wheat entries for the presence of important $\mathrm{Lr}$ genes were screened, and 17 out of 30 entries carried $L r 1$, while six carried $L r 26$ and $L r 34$, three carried Lr10 and Lr37, two carried Lr19 and Lr68. The highest resistance was found in five Kazakh and in two foreign cultivars (Kokhmetova et al. 2016).

A collection of 64 common wheat germplasms was evaluated for tan spot Pyrenophora tritici-repentis resistance in greenhouse, using the molecular marker Xfcp623, diagnostic for the Tsn1 gene. Most of the entries were susceptible to Ptr race 1 . As a result, 27 wheat entries with resistance to race 1 , combined with resistance to Ptr ToxA and field resistance, were selected (Kokhmetova et al. 2019).

Sensitivity to Ptr ToxB is not always correlated with susceptibility to race 5 and is dependent on the genetic background of the host. These results are a subject of interest for increasing the efficiency of breeding, based on the elimination of genotypes with dominant alleles $T s n 1$ and $T s c 2$, sensitive to toxins Ptr ToxA and ToxB (Kokhmetova et al. 2018a, b).

Molecular genetic certification of domestic apple cultivars grown in Kazakhstan was also carried out, in which disease-resistant genotypes of domestic and wild apple trees were identified. A DNA bank of 71 domestic apple cultivars growing in Kazakhstan was established at the IPBB, revealing differences between the genotypes of some apple cultivars. For the first time, a molecular-genetic approach was applied using markers based on chloroplast DNA. Data on 17 microsatellite and 2 chloroplast markers were used to create genetic passports of 71 apple cultivars. Varieties and genotypes of wild apple trees with one or both loci associated with resistance to bacterial burns were identified; one of the genotypes resistant to apple bacterial burn is also potentially resistant to scab (Omasheva et al. 2018).

The Institute of Plant Biology and Biotechnology was a member of the 7th European framework program "Genetics and Physiology of Wheat Development before the Flowering Phase: New Selection Methods to Improve Adaptation and Yield Potential". The consortium included 20 research teams from around the world, with a project duration from 2012 to 2015 . Within the framework of the program, 90 spring wheat varieties of Kazakhstan, registered in the GSI Ministry of Agriculture of the Republic of Kazakhstan, were genotyped using a chip for 90,000 SNP markers, applying the new-generation technology of Illumina Ltd. Results were obtained for 65,000 SNP markers, of which 35,000 were identified as polymorphic for the studied 90 varieties. The same set of varieties was simultaneously studied in the field of breeding institutions in Northern, Central and Southern Kazakhstan (Turuspekov et al. 2017a, b). 
In collaboration with the John Innes Center (Norwich, UK), a genetic map of hexaploid wheat from crossing varieties of Pamyat Aziev (Russia) and Paragon (Great Britain) was constructed. The genetic population of common wheat consists of 92 recombinantly inbred lines, studied using the Illumina chip technology for 15,000 SNP markers (Amalova et al. 2019).

The IPBB developed DNA passports of domestic varieties of wheat, barley, rice, oats, soybeans, using DNA markers. Valuable genotypes of wheat and barley were identified and characterised by high yields and grain quality. For the first time, using the associative gene mapping method, new DNA markers were identified, which are associated with resistance to the most dangerous barley diseases in Kazakhstan-stem rust and dark brown spotting. The results obtained here allow breeding studies of grain and leguminous crops at the genomic level (Abugalieva et al. 2016; Kokhmetova et al. 2017; Turuspekov et al. 2016; Volis et al. 2016).

In cooperation with the Ministry of Agriculture and independently over the past few years, the IPBB created and transferred to the state variety test new highly productive and stress-resistant environmental varieties of agricultural crops (12 varieties-wheat, barley, rice).

\section{Cell and tissue culture in plant breeding}

On a global level, there is a high competition among varieties and hybrids of crops, which has led to the fact that along with traditional methods of selection, biotechnologies are intensively applied to increase the efficiency of the selection process. In particular, in vitro culture allows selection at the level of cells and tissues for tolerance to environment stress factors, enhancing selection mutagens. Somatic cells and tissues, isolated microspores and nuclei of distant hybrids, etc. are used as explants. All of these methods are widely used in scientific studies in Kazakhstan.

In the IPBB, on the basis of haploid biotechnology, double haploid interspecific hybrid rapeseed lines with rape and mustard are created as the starting material for creating drought-resistant domestic rapeseed varieties. At the same time, a GISH analysis of plants showed the presence of donor sections of chromosomes of Brassica rapa and Brassica juncea in the genome of doubled haploids of rape hybrids, which confirmed the successful hybridisation process. Assessment of drought tolerance during germination of doubled haploid interspecific hybrid seeds on PEG 6000 showed the superiority of hybrid seeds during germination and the relative water content in seedlings, which proves the superiority of hybrid forms in relation to the parent. Double haploid interspecific hybrid lines are transferred to Kazakhstan breeding centres specialising in the breeding and testing of new varieties of rapeseed.
Based on cell and tissue culture methods, perspective lines of wheat, barley, sorghum, rape, safflower and rice with economically valuable traits are created for inclusion in breeding programs, aiming at the creation of new varieties (Rysbekova et al. 2016; Zhambakin et al. 2014).

Based on cell and tissue culture methods, the National Center for Biotechnology has created four high-yielding varieties of spring soft wheat, namely "Kazakhstan-20", "Ak Orda", "Darkhan-Don" and "Shabyt". Competitive and environmental varietal tests were conducted in the regions of Akmola, Kostanai, Pavlodar and Karaganda, and zoning of these varieties is currently underway in various regions of the country. Competitive and environmental varietal tests were conducted in Akmola, Kostanai, Pavlodar and Karaganda, and the large-scale industrial cultivation of these varieties in various regions of the country is underway. The new potato variety "Astanalyk" resistant to fungal diseases has been created, and state variety testing was carried out in Akmola and Almaty. In 2016, three patents of selection achievement for the created spring soft wheat varieties "Kazakhstan-20" and "Ak Orda" and for the potato variety "Astanaalyk" were obtained (Ali et al. 2010; Kakimzhanova et al. 2013; Shek et al. 2011; Turganbayeva et al. 2013).

\section{Genetic engineering}

Genetic engineering is the most effective method for obtaining plant lines with targeted traits, in particular against the background of the recent developments in molecular genetics.

The IMBB has been using methods for producing transgenic plants resistant to phytopathogenic viruses, drought and cold for a long time, developing transgenic tobacco and potato plants expressing antisense RNAs complementary to different regions of the genomic RNA of the potato virus Y. Several lines of transgenic potato were submitted for experiments to the Institute of Potato and Vegetables (NIIKOH) of the Ministry of Agriculture of the Republic of Kazakhstan, and numerous lines of transgenic potato showed significant resistance to Y-virus and are therefore promising for further selection. By inducing RNA interference, GM potato lines with multiple resistance to the viruses PVY, PVM, PVS (Karpova et al. 2017) were obtained.

There are highly developed new technologies for the production of transgenic bacteria and plants as well as transplastomic plants to produce recombinant vaccine proteins against sheep pox virus (SPPV), in addition to proteins significant for medicine (human alpha-fetoprotein, hAFP) (Chervyakova et al. 2016).

The IPBB has developed a viral vector using a deconstructed virus strategy for the production of recombinant proteins in plants. The genome of the grape virus A has been 
Table 1 Volume of services provided for research and development, by type of service (Belyaeva et al. 2019)

\begin{tabular}{|c|c|c|c|c|c|}
\hline & 2014 & 2015 & 2016 & 2017 & 2018 \\
\hline Research and experimental development services in the field of biotechnology (health) & 1.7 & 4.5 & 2.6 & 1.87 & 2 \\
\hline Research and experimental development services in the field of biotechnology (ecology and industry) & 7.6 & 3.8 & 4.6 & 3.6 & 5.1 \\
\hline Research and experimental development services in the field of biotechnology (agriculture) & 18.4 & 4.8 & 3.1 & 3.3 & 4.4 \\
\hline Services in research and advanced development in the field of biotechnology & 4.9 & 3.4 & 4.6 & 4.1 & 3.5 \\
\hline
\end{tabular}

MM. US dollar

modified to clone a recombinant gene instead of the virus envelope protein gene. The bird flu hemagglutinin (HA) gene is cloned into the viral vector, and using agroinfiltration of $N$. benthamiana, the HA gene is transiently expressed in plants and isolated by metal chelate chromatography (Gritsenko et al. 2019). As a result, transgenic rapeseed lines resistant to abiotic stress factors were obtained.

The IPBB employees, in cooperation with the IMBB, the genetic agrotransformation of the rape haploid plants hypocotyls with the target $A t C B F 3$ gene has been performed. Cytological analysis for ploidy was carried out, followed by doubling of the chromosomes and transplanting into the soil under controlled conditions. Dihaploid transgenic lines were obtained, and the desired insert and transgene expression was confirmed. The obtained lines showed increased resistance to cold compared with the control under laboratory conditions (Nargilova et al. 2014).

For more than 5 years, the IPBB, in collaboration with the Korean Research Institute of Bioscience and Biotechnology (KRIBB), has been jointly researching the introduction of sweetpotato into Kazakhstan (Daurova et al. 2017, Daurov et al. 2018). However, sweetpotato is still not grown at an industrial scale in Kazakhstan, despite its value for a healthy diet.

First experiments on the cultivation of sweetpotato in Kazakhstan have shown certain risks associated with low positive temperatures that may occur in South Kazakhstan during the growth period.

In this regard, further joint research aimed at obtaining cold-resistant lines of sweetpotato, using genetic transformation. Promising genes were identified, including for $I b C B F 3$, IbBZRI and IbWRKY3I (Zhapar et al. 2019). According to literature data, those genes play key roles in plants under abiotic and biotic stress. A construct with target genes and the stress-inducible promoter SWPA2 was created; stressinducible promoters were chosen as they are regulated by stress factors that trigger the expression mechanisms.

An Agrobacterium transformation with the target genes $(I b C B F 3, I b B Z R 1, I b W R K Y 31)$ was also carried out and transgenic plants were obtained; those plants will be tested for resistance to abiotic stresses.

In the future, due to the achievements of breeding and biotechnology, it will be possible to eliminate the main limiting factors for growing heat-demanding plants in northern regions. In addition, the sustainability and productivity of tropical plants that are already being cultivated will increase.

\section{Conclusions}

This review provides information on the most significant results in the field of plant biotechnology in Kazakhstan. We did not include the results from the production of virus-free planting material of vegetatively propagated crops, since Kazakhstan still has certain problems, despite years of scientific and production work in this area, mainly due to insufficient monitoring of viruses in the planting stock.

Unfortunately, over the past 5 years, no increase in the cost of biotechnological services rendered; on the contrary, in most areas, there was a significant decrease (Belyaeva et al. 2019) (Table 1). This situation is alarming, since the condition of biotechnological services is one of the main indicators of the successful development of the country's economy.

The further development of plant biotechnology in the country is associated with an acute need for the conservation and study of plant genetic resources at the global level, primarily for practical and commercial purposes. To increase the efficiency of the breeding process, it will be necessary to develop molecular genetics, cellular and genetic engineering, as well as to edit crop genomes. Such a development is impossible without a significant increase in funds, both from state and private investments.

Acknowledgements This article was supported by the governmental program of the Republic of Kazakhstan «The Development of Advanced Technologies to Produce Crops Resistant to Stress Factors in Utilizing Adaptive Mechanisms of Plants» (Prog. No. STP O.0798) and «Mutagenesis in vitro for Production of High Quality and High-oleic Oil Lines of B. napus, B. rapa and their Hybrids» (No. AP05130871).

Funding Funding was provided by Ministry of Education and Science of the Republic of Kazakhstan.

Open Access This article is licensed under a Creative Commons Attribution 4.0 International License, which permits use, sharing, adaptation, distribution and reproduction in any medium or format, as long as you give appropriate credit to the original author(s) and the source, provide a link to the Creative Commons licence, and indicate if changes were made. The images or other third party material in this article are 
included in the article's Creative Commons licence, unless indicated otherwise in a credit line to the material. If material is not included in the article's Creative Commons licence and your intended use is not permitted by statutory regulation or exceeds the permitted use, you will need to obtain permission directly from the copyright holder. To view a copy of this licence, visit http://creativecommons.org/licenses/by/4.0/.

\section{References}

Abugalieva S, Didorenko S, Anuarbek S, Volkova L, Gerasimova Y, Sidorik I, Turuspekov Y (2016) Assessment of soybean flowering and seed maturation time in different latitude regions of Kazakhstan. PLoS ONE 11(12):e0166894

Abugalieva S, Volkova L, Genievskaya Y, Ivaschenko A, Kotukhov Y, Sakauova G, Turuspekov Y (2017) Taxonomic assessment of Allium species from Kazakhstan based on ITS and matK markers. BMC Plant Biol 17(2):258

Adekenov SM (2016) Chemical modification of arglabin and biological activity of its new derivatives. Fitoterapia 110:196-205

Adekenov SM (2017) Sesquiterpene lactones with unusual structure. Their biogenesis and biological activity. Fitoterapia 121:16-30

Akbergenov RZ, Zhanybekova SS, Polimbetova NS, Madin KI, Hohn T, Iskakov BK (2003) Complementary interaction between the central domain of $18 \mathrm{~S}$ rRNA and the $5^{\prime}$ untranslated region of mrna enhances translation efficiency in plants. In: Swartz JR (ed) Cell-free protein expression. Springer, Berlin

Akbergenov RZ, Zhanybekova SS, Kryldakov RV, Zhigailov A, Polimbetova NS, Hohn T, Iskakov BK (2004) ARC-1 a sequence element complementary to an internal $18 \mathrm{~S}$ rRNA segment, enhances translation efficiency in plants when present in the leader or intercistronic region of mRNAs. Nucleic Acids Res 32(1):239-247

Ali AM, Kakimzhanova AA, Karimova VK (2010) Method for producing virus-free potato minitubers at the aeroponic installation. Patent RK N 22559, 2010/06/15.

Almerekova S, Mukhitdinov N, Abugalieva S (2017) Phylogenetic study of the endemic species Oxytropis almaatensis (Fabaceae) based on nuclear ribosomal DNA ITS sequences. BMC Plant Biol 17(S1):19-27

Amalova AY, Yermekbayev KA, Griffiths S, Abugalieva SI, Turuspekov YK (2019) Phenotypic variation of common wheat mapping population Pamyati Azieva x Paragon in south-east of Kazakhstan. Int J Biol Chem 12(1):11-17

Bari GT, Zheksenbay AN, Danilenko MP, Uteulin KR (2014) The effect of licorice extracts on the proliferation of HL60 myeloid leukemia cells. KazNU Bull Biol Ser 1/2(60):71-173

Batyrshina Z, Yergaliyev TM, Nurbekova Z, Masalimov ZK, Sagi M, Omarov RT (2018) Differential influence of molybdenum and tungsten on the growth of barley seedlings and the activity of aldehyde oxidase under salinity. J Plant Physiol 19:189-196

Belyaeva GN, Kubieva T, Kozbagarova GA, Ponomareva NI (2019) The science of Kazakhstan in numbers, (2014-2018): inform guide. SC STE, Almaty

Chervyakova OV, Zaitsev VL, Iskakov BK, Tailakova ET, Strochkov VM, Sultankulova KT, Sandybayev NT, Stanbekova GE, Beisenov DK, Abduraimov YO, Mambetaliyev M, Sansyzbay AR, Kovalskaya NY, Nemchinov LG, Hammond RM (2016) Recombinant sheep pox virus proteins elicit neutralizing antibodies. Viruses 8(159):1-13

Daurov D, Zhapar K, Daurova A, Volkov D, Bakbergenova M, Tolegenova D, Shamekova M, Zhambakin K (2018) Production of virus-free sweetpotato planting material for the southeast of Kazakhstan. Int J Agric Biol 20:851-856
Daurova AK, Daurov DL, Zhapar KK, Volkov DV, Zhambakin KZ, Shamekova MK (2017) Obtaining transgenic sweetpotato plants with the DREB1A gene. News of NAS RK. Biol Med Ser 2:71-77

Galiakparov NN, Omasheva MY, Smailov BB, Pozharskiy AS (2019) Set of synthetic oligonucleotides for diagnosis of bacterial blight on fruit crops using of LAMP method. Patent RK N 33633, 2019/05/14

Gritsenko DA, Kenzhebekova RT, Deryabina ND, Galiakparov NN (2019) Development of a "deconstructed" vector based on the genome of grapevine virus A. Plant Biotechnol Rep 13(2):169-177

Joldybayeva B, Prorok P, Grin IR, Zharkov DO, Ishenko AA, Tudek B, Bissenbaev AB, Saparbaev M (2014) Cloning and characterization of a wheat homologue of apurinic/apyrimidinic endonuclease Ape1L. PLoS ONE 9(6):e101795

Kakimzhanova A, Karimova V, Magzumova G (2013) Creating valuable forms and varieties of potatoes that are resistant to fungal diseases. Curr Opin Biotechnol 24(1):125

Karpova O, Aleksandrova A, Nargilova R, Iskakov B (2017) Expression of potato virus $\mathrm{S}$ gRNA fragments in transgenic potato plants triggers RNA-interference against related and unrelated viruses. J Biotechnol 256:105

Kokhmetova AM, Morgounov A, Rsaliyev S, Yessenbekova G, Tyupina L (2011) Wheat germplasm screening for stem rust resistance using conventional and molecular techniques. Czech J Genet Plant Breed 47:146-154

Kokhmetova A, Madenova A, Purnhauser L, Kampitova G, Urazaliev R, Yessimbekova M (2016) Identification of leaf rust resistance genes in wheat cultivars produced in Kazakhstan. Cereal Res Commun 44(2):240-250

Kokhmetova A, Kremneva O, Volkova G, Atishova M, Sapakhova Z (2017) Evaluation of wheat cultivars growing in Kazakhstan and Russia for resistance to tan spot. J Plant Pathol 99(1):161-167

Kokhmetova AM, Ali S, Sapahova Z, Atishova MN (2018a) Identification of genotypes-carriers of resistance to toxins Ptr ToxA and Ptr ToxB Pyrenophora tritici-repentis in collection of common wheat. Vavilov J Gen Breed 22(8):978-986

Kokhmetova A, Sharma R, Rsaliyev S, Galymbek K, Baymagambetova K, Ziyaev Z, Morgounov A (2018b) Evaluation of Central Asian wheat germplasm for stripe rust resistance. Plant Genet Resour 16(2):178-184

Kokhmetova A, Atishova M, Kumarbayeva M (2019) Phytopathological screening and molecular marker analysis of wheat germplasm from Kazakhstan and CIMMYT for resistance to tan spot. Vavilov J Gen Breed 23(7):879-886

Kushnarenko SV, Karasholakova LN, Ozek G, Abidkulova KT, Mukhitdinov NM, Baser КНC, Оzек T (2016) Investigation of essential oils from three natural populations of Lonicera iliensis. Chem Nat Compd 52(4):751-753

Kushnarenko S, Romadanova N, Aralbayeva M, Zholamanova S, Alexandrova A, Karpova $\mathrm{O}$ (2017) Combined ribavirin treatment and cryotherapy for efficient potato virus $\mathrm{M}$ and potato virus $\mathrm{S}$ eradication in potato (Solanum tuberosum L.) in vitro shoots. In Vitro Cell Dev Biol Plant 53(4):425-432

Nargilova RM, Shadymova EA, Pisarenko AM, Karpova OV (2014) Obtaining transgenic plants expressing the gene for transcription factor AtCBF3. In: International Scientific Conference on Plant Biol and Biotechnol. Almaty, Kazakhstan.National Science Report (2018) Almaty: Nat Acad Sci Rep Kaz, p 120

Nurzhanova A, Kalugin S, Zhambakin K (2013) Obsolute pesticides and application of colonizing plant species for remediation of contaminated soils in Kazakhstan. Environ Sci Pollut Res 20:2054-2063

Nurzhanova A, Pidlisnyuk V, Abit K, Nurzhanov Ch, Kenessov B, Stefanovska T, Erickson L (2019) Comparative assessment of using Miscanthus $\times$ giganteus for remediation of soils contaminated by 
heavy metals: a case of military and mining sites. Environ Sci Pollut Res 26(13):3320-13333

Omasheva ME, Pozharsky AS, Smailov BB, Ryabushkina NA, Galiakparov NN (2018) Genetic diversity of apple cultivars growing in Kazakhstan. Rus J Genet 54(2):176-187

Romadanova NV, Mishustina SA, Matakova GN, Kushnarenko SV, Rakhimbaev IR, Reed BM (2016a) In vitro collection of Malus shoot culture for cryogenic bank development in Kazakhstan. Acta Hortic 1113:271-277

Romadanova NV, Mishustina SA, Gritsenko DA, Omasheva MY, Galiakparov NN, Reed BM, Kushnarenko SV (2016b) ) Cryotherapy as a method for reducing the virus infection of apples (Malus sp.). CryoLetters 37(1):1-9

Rysbekova AB, Kazkeev DT, Usenbekov BN, Mukhina JM, Zhanbyrbaev EA, Sartbaeva IA, Zhambakin KZ, Berkimbay HA, Bataeva DS (2016) Selection of pre-selection material with colored pericarp based on genotyping of Rc and Pb genes. Genet 10:1-11

Schepetkin IA, Kushnarenko SV, Özek G, Kirpotina LN, Utegenova GA, Kotukhov YA, Danilova AN, Özek T, Başer KHC, Quinn MT (2015) Inhibition of human neutrophil responses by essential oil of Artemisia kotuchovii and its constituents. J Agric Food Chem 63:4999-5007

Schepetkin IA, Kushnarenko SV, Özek G, Kirpotina LN, Utegenova GA, Abidkulova KT, Özek T, Başer KHC, Kovrizhina AR, Khlebnikov AI, Quinn MT (2016) Modulation of human neutrophil responses by the essential oils from Ferula akitschkensis and their constituents. Agric Food Chem 64(38):7156-7170

Schepetkin IA, Kirpotina LN, Mitchell PT, Kishkentaeva AS, Shaimerdenova ZR, Atazhanova GA, Adekenov SM, Quinn MT (2018) The natural sesquiterpene lactones arglabin, grosheimin, agracin, parthenolide, and estafiatin inhibit $\mathrm{T}$ cell receptor (TCR) activation. Phytochemistry 146:36-46

Shek GO, Turganbaeva AK, Kakimzhanova AA (2011) Positive decision No. 2011/097.4 of November 29, 2011 for the new wheat grade "Kazakhstan 20"

Suleimenov EM, Tkachev AV, Adekenov SM (2010) Essential oil from Kazakhstan Artemisia species. Chem Nat Compd 46(1):135-139

The World Bank data (2017) Research and development expenditure (\% of GDP). https://data.worldbank.org/indicator/GB.XPD.RSDV. GD.ZS

Turganbayeva A, Hapilina O, Shek G (2013) Development important forms of soft spring wheat in North Kazakhstan. Curr Opin Biotechnol 24(1):127
Turuspekov Y, Ormanbekova D, Rsaliev A, Abugalieva S (2016) Genome-wide association study on stem rust resistance in Kazakh spring barley lines. BMS Plant Biol 16(1):13-21

Turuspekov Y, Genievskaya Y, Baibulatova A, Zatybekov A, Kotuhov Y, Imanbayeva A, Abugalieva S (2017a) Phylogenetic taxonomy of Artemisia L. species from Kazakhstan based on matK analyses. Proc Latvian Acad Sci 72:29-37

Turuspekov Y, Plieske J, Ganal M, Akhunov E, Abugalieva S (2017b) Phylogenetic analysis of wheat cultivars in Kazakhstan based on the wheat $90 \mathrm{~K}$ single nucleotide polymorphism array. Plant Genet Resour 15(1):29-35

Utegenova G, Pallister K, Kushnarenko S, Ozek G, Ozek T, Abidkulova K, Kirpotina L, Schepetkin I, Quinn M, Voyich J (2018) Chemical composition and antibacterial activity of essential oils from Ferula L. species against methicillin-resistant Staphylococcus aureus. Molecules 23(7):1679-1696

Uteulin KR, Baitulin IO (2017) On the need to restore degraded populations of kok-saghyz. Rep Natl Acad Sci Rep Kaz 312(2):56-61

Uteulin KR, Rakhimbaev I, Baitulin IO, Zhambakin KZ (2018) Certificate of the author of the selection achievement. Variety of dandelion, kok-sagyz "Saryzhaz" No. 4395. RSE "National Institute of Intellectual Property" of the Ministry of Justice of the Republic of Kazakhstan

Volis S, Ormanbekova D, Yermekbayev K, Abugalieva S, Turuspekov Y, Shulgina I (2016) Genetic architecture of adaptation to novel environmental conditions in a predominantly selfing allopolyploid plant. Heredity 116:485-490

Zhambakin KZ, Zatybekov AK, Volkov DV, Shamekova MH (2014) Production of rapeseed mutant lines by male gametophyte culture. J Biotechnol 185:29-30

Zhapar KK, Shamekova MK, Zhambakin KZ (2019) Gene engineering for production cold-tolerant sweetpotato (ipomoea batatas). Rep Natl Acad Sci Rep Kaz 1(323):29-39

Publisher's Note Springer Nature remains neutral with regard to jurisdictional claims in published maps and institutional affiliations. 